\title{
TEMPERATURE PREFERENCES OF FOUR SPECIES OF FIRE ANTS (HYMENOPTERA: FORMICIDAE: SOLENOPSIS)*
}

\author{
By James C. Cokendolpher' and OsCar F. Francke ${ }^{2}$
}

\section{INTRODUCTION}

Temperature preferences are predicted to occur in insects due to homeostatic considerations. Enzymes should be adapted to function optimally within the narrow range of temperatures encountered by an organism during its peak activity periods (Heinrich, 1981). In ectotherms adapted to function optimally at low temperatures (e.g., living at higher latitudes or higher elevations), their biochemical machinery becomes inactivated or denatured at high temperatures. Conversely, those adapted to function optimally at high temperatures (e.g., living in the tropics or at lower elevations), experience reduced rates of biochemical activity at lower temperatures. Optimality theory predicts that ectotherms which habitually encounter temperature gradients should have the physiological and behavioral adaptations necessary to detect and respond to those gradients.

A temperature gradient which fluctuates with daily and seasonal changes in solar radiation exists in the soil. This gradient is used by ground-nesting organisms to achieve some thermoregulatory homeostasis: they can move up and down their burrows to avoid temperature extremes, especially those occurring near the soil surface. Superimposed on this temperature gradient is a moisture gradient, because the higher temperatures reached at the soil surface during the day promote evaporation. Ants which nest in the soil are known to respond to the temperature/humidity gradients in the soil, and this response is particularly noticeable by the movement of brood among the various nest chambers (Ceusters, 1977; Seeley and Heinrich, 1981). Our research has focused on the responses of four species of fire ants to these soil gradients: elsewhere we (Potts et al.,

'Department of Entomology and 'Department of Biological Sciences, Texas Tech University, Lubbock, Texas 79409.

"Manuscript received by' the editor Dec'ember 27, 1984. 
1984) examined their responses to humidity gradients in the absence of superimposed thermal gradients, and here we examine their responses to temperature gradients in the absence of superimposed humidity gradients.

Numerous variables have been reported to alter temperature preferences in insects: age, sex, desiccation, hunger, rearing and maintenance temperatures prior to experiments (Deal, 1941; Madge, 1965), relative humidity (Gunn and Cosway, 1938; Deal, 1941), aggregation (Henson, 1960), and experiment duration (Deal, 1941; Ferguson and Land, 1961). In this study treatments consisted of three acclimation temperatures and two experimental relative humidities.

Temperature preferences have been previously investigated in only a few species of ants. Furthermore, the results obtained from most of those studies (Herter, 1923-1925; Hertzer, 1930; Bodenheimer and Klein, 1930: all cited in Deal, 1941) are either inconclusive or the reliability of the measurements are suspect. Although Deal's (1941) study of preference in Acanthomyops sp. is not very precise, it demonstrates that the preferred temperature in that species increases with an increase in relative humidity. The temperature preferences of the ant Formica polyctena Foerst were reported by Ceusters (1977). In that study a temperature gradient ranging from about 10 to $30^{\circ} \mathrm{C}$ was established in a battery of 14 consecutive nest cells and numbers of individuals (of workers, queens, eggs, each larval stage, and pupae) were recorded through 12 brood rearing periods (four years). Ceusters (1977) found that each development stage had a different "preferred" temperature, except the differences between eggs/ hatchling larvae and small larvae were not statistically significant. Brian (1973), working with the ant Myrmica rubra L., determined temperature preferences with both an alternate temperature chamber and a linear gradient chamber. The preferences of the ant Camponotus mus Roger, have been investigated by Protomastro (1973). The optimal rearing temperature and thermal preference were considered to be the same by Protomastro (1973).

Few studies have compared temperature preferences among more than two congeneric insect species. The primary objective of this study was to compare the temperature preferences of four fire ant species of the genus Solenopsis Westwood. These four species differ in their ecogeographical distributions: one is xerophilous, two are mesophilous, and one is widespread. The northern limits of distribu- 
tion in North America of the four species studied are between $35^{\circ}$ and $37^{\circ}$ north latitude. Solenopsis aurea Wheeler, the desert fire ant, generally does not occur east of the 100th meridian, whereas Solenopsis geminata (Fabricius), the tropical fire ant, and Solenopsis invicta Buren, the red imported fire ant, generally do not occur west of the 100th meridian. Solenopsis xyloni McCook, the southern fire ant, occurs across the U. S. from coast to coast (Francke $e t$ al., 1983). Thus, we sought correlations among the species' temperature preferences in the laboratory and their observed ecogeographic distributions.

\section{Materials ANd Methods}

The position to which an insect will move in a thermal gradient indicates its preferred temperature. Orientation and movement in the gradient are stimulated by reactions of avoidance, attraction, or a combination (Deal, 1941). Extensive literature exists on preferred temperatures of terrestrial arthropods (see Bull and Mitchell, 1972; Fraenkel and Gunn, 1961; Mori, 1961; Protomastro, 1973; Singh et al., 1967; and citations contained therein, particularly Deal, 1941). Two types of devices are generally used in these investigations: alternate chambers with temperature ranges of only a few degrees, and a gradual gradient chamber (linear or circular). In either case the movement of individuals or the final distribution of a large number of insects is recorded as a measure of temperature preference.

Temperature is not the only variable in a temperature gradient apparatus. For a review of devices and associated problems, see Fraenkel and Gunn (1961), Madge (1965), and citations contained therein. In the present experiments, like Bull and Mitchell (1972), we attempted to reduce the effects of the non-temperature variables as identified by Madge (1961) by using: (a) a porous false floor, so that the substrate temperature would not differ significantly from the air temperature immediately surrounding it; (b) a large gradient chamber to promote microclimatic stability; and (c) atmospheres as near $0 \%$ and $100 \% \mathrm{R}$. H. as possible to minimize the effects of moisture gradients on the ants' preferences.

A linear temperature gradient apparatus, slightly modified from that of Bull and Mitchell (1972), was used for the studies (Fig. 1). The lid of the chamber was fitted with three magnets (one on top, 


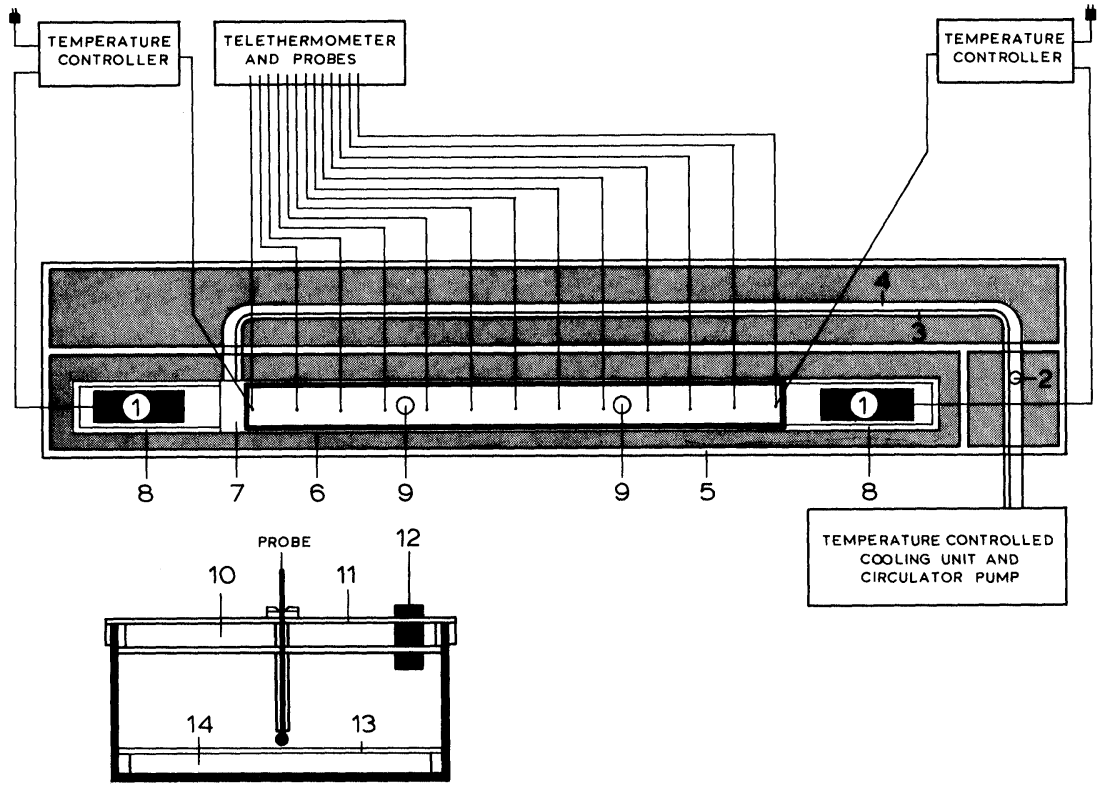

Fig. 1. Linear temperature gradient apparatus, semi-schematic. A. View from above of gradient chamber and associated equipment. B. View of cross section through Plexiglas test chamber. Shaded areas are polystyrene foam insulation. 1, strip heaters; 2 , valve for controller flow rate of coolant; 3 , cold water input conduit; 4, cold water return conduit; 5 , wooden housing for chamber and closely associated parts; 6 , Plexiglas test chamber; 7 , cold water compartment for cooling aluminum channel; 8, aluminum channel for housing Plexiglas test chamber; 9, introduction ports for test animals: 10, dead air space; 11, lid of test chamber; 12, "condensate wipers", magnets: 13, porous substrate; 14, space for humidity controlling substances; see text for further details.

one in $1.5 \mathrm{~cm}$ dead air space, and one below), which were used as "condensate wipers"(Fig. 1B-12). By adjusting the two temperature controllers and the flow rate of the coolant, a linear temperature gradient between $15^{\circ}$ and $35^{\circ} \mathrm{C}$ was obtained. A constant $22 \pm 1^{\circ} \mathrm{C}$ was obtained by turning off both strip heaters and the water bath pump. During the experiments two humidities were employed. A saturated atmosphere was obtained by placing wet paper toweling beneath the substrate in the test chamber (Fig. 1B-14), and 0\% R. $\mathrm{H}$. was obtained by the use of Drierite $\left(\mathrm{CaSO}_{4}\right)$. 
Four species of fire ants (Solenopsis spp.) from Texas were used: S. invicta Buren from Bandera, Kerr, and Harris Counties; S. geminata (Fabricius) from Kimble and Val Verde Counties; S. xyloni McCook from Bandera, Garza, Kerr, Kimble and Nolan Counties; $S$. aurea Wheeler from Garza, Lubbock, and Reeves Counties. All ants were collected during the summer months except for some $S$. invicta: those from Kerr County (1 April) and Harris County (11 January). The colonies were maintained in the dark at three different temperatures $\left(12 \pm 2^{\circ}, 22 \pm 2^{\circ}, 32 \pm 2^{\circ} \mathrm{C}\right)$ for a minimum of 14 days prior to experiments. Colonies of ants were collected, separated from the soil, and housed following the methods of Banks et al. (1981). All colonies were maintained similarly, being fed cockroaches [Nauphoeta cinerea (Saussure)], and mealworms [Tenebrio sp.], and supplied free water and a $50 \%$ aqueous honey solution daily.

Worker ants without brood failed to make "scorable" choices in the linear temperature gradient. Therefore, workers with brood (larvae and pupae) were utilized. For both experimental and control studies, approximately 25-50 individuals of all worker castes and some brood were introduced to the test chamber via entrance ports located in the lid approximately $35 \mathrm{~cm}$ from each end (Fig. 1A-9). Preliminary studies indicated that ants given less than two hours would not settle into a clump; therefore, the ants were allowed at least two hours to move the brood and settle. The temperature where the ants settled was recorded at the termination of each experiment. Like Brian (1973), we found that pheromones left by the ants attracted conspecifics during the following trials. This interference was eliminated by exposing the substrate to light (lid of chamber removed) from a Sylvania Black Light Blue Fluorescent Lamp, F15T8/BLB, at a distance of $30 \mathrm{~cm}$ for at least one hour after each trial. After exposure to U.V. light, the chamber was resealed and allowed to equilibrate (humidity and temperature) for at least one hour.

Control trials differed only by having a constant temperature throughout the test chamber $\left(22 \pm 1^{\circ} \mathrm{C}\right)$. The number of replications and the number of colonies used per species varied, depending on the number of brood tending ants which could be obtained (Table 1).

To determine if the ants showed any preferences during control trials, the Kolmogorov-Smirnov test was used (Siegel, 1956). Differ- 
Table 1. Effects of acclimation on temperature preferences of Solenopsis xyloni and $S$. invicta collected during the winter.

\begin{tabular}{lcccr}
\hline Species & $\begin{array}{c}\text { Relative Humidity } \\
(\%)\end{array}$ & $\begin{array}{c}\text { Acclimation } \\
\left({ }^{\circ} \mathrm{C}\right)\end{array}$ & $\begin{array}{c}\text { Temperature Preference } \\
(\overline{\mathrm{x}} \pm \text { s.d.. }\end{array}$ & $\mathrm{N})$ \\
\hline S. invicta & 0 & 12 & $23.8 \pm 1.8$ & 10 \\
& 0 & 22 & $23.2 \pm 1.3$ & 15 \\
& 0 & 32 & $21.0 \pm 2.4$ & 10 \\
& 100 & 12 & $27.5 \pm 1.2$ & 10 \\
& 100 & 22 & $29.7 \pm 2.6$ & 15 \\
S. xy.loni & 100 & 32 & $25.3 \pm 2.8$ & 11 \\
& 0 & 12 & $24.9 \pm 1.1$ & 5 \\
& 0 & 22 & $25.4 \pm 2.2$ & 10 \\
& 0 & 32 & $24.8 \pm 3.5$ & 5 \\
& 100 & 12 & $27.2 \pm 1.8$ & 12 \\
& 100 & 22 & $29.7 \pm 2.4$ & 10 \\
& 100 & 32 & $26.0 \pm 2.4$ & 7 \\
\hline
\end{tabular}

ences among species and between $S$. invicta collected during summer and winter months were analyzed with the General Linear Regressions Models and Analysis of Variance of S. A. S. (Helwig and Council, 1979.)

\section{RESULTS}

The control responses of each of the four species were analyzed separately with the Kolmogorov-Smirnov test using the null hypotheses that the observed distribution should not differ from the predicted theoretical frequency distribution of the same number of responses on each of the twelve areas in the chamber. The maximum deviation (D) acceptable at the 0.05 confidence level under the specified theoretical cumulative distribution is $D=0.294, N=20$. The results were $S$. aurea $\mathrm{D}=0.218 ; S$. geminata $\mathrm{D}=0.120 ; S$. invicta $\mathrm{D}=0.117$; and $S$. xyloni $\mathrm{D}=0.168$. Therefore, the null hypothesis was accepted for each of the four species: During the control tests the ants exhibited no preference for any part of the experimental chamber.

Analysis of variance indicated that species identity $[\mathrm{F}(3,269)=$ 7.2], relative humidity $[F(1,269)=183.7]$, and acclimation $[F(2,269)$ $=10.2]$ were all highly significant $(p<0.001)$ during experimental trials. None of the two way interactions were significant $(p>0.05)$, but the three way interaction (R. H. $\times$ acclimation $\times$ species) was $[F(6,269)=2.7,0.05>p>0.01]$. 
Intraspecific analyses of temperature preferences indicated that relative humidity was highly significant $(\mathrm{p}<0.001)$ for all species: in $S$. aurea $\mathrm{F}(1,50)=19.6 ; S$. geminata $\mathrm{F}(1,48)=65.4$; in summer collected $S$. invicta $\mathrm{F}(1,57)=38.3$, and in winter collected ants $\mathrm{F}(1,65)=99.2$; and finally in $S$. xyloni $\mathrm{F}(1,43)=16.4$. The two way interaction (R. H. $\times$ acclimation) was significant only for S. geminata $[\mathrm{F}(2,48)=7.8,0.01>\mathrm{p}>0.001]$. The temperature preference responses of the four species of fire ants at both $0 \%$ and $100 \% \mathrm{R}$. H. appear in Fig. 2.

Acclimation was significant only with $S$. xyloni $[\mathrm{F}(2,43)=4.2$, $0.05>\mathrm{p}>0.01]$, and individuals of $S$. invicta collected during the winter $[F(2,65)=15.4, p<0.001]$ (Table 1). Solenopsis invicta collected during the summer months showed no acclimation effects $[F(2,57)=1.3, p>0.05]$.

\section{Discussion}

The ability to react rapidly to temperature gradients by the four species of fire ants, and the effect of relative humidity on this response have obviously been shaped by strong selective pressures. In all intraspecific pair-wise (with respect to acclimation) comparisons possible, ants at $0 \% \mathrm{R}$. $\mathrm{H}$. had a lower temperature preference by about $3-4^{\circ} \mathrm{C}$ with respect to those at $100 \% \mathrm{R}$. H. Each experimental trial lasted a minimum of two hours, indicating that the ants can perceive and respond to the lower, but constant, relative humidity despite the superimposed temperature gradients in a relatively short period of time. This reaction time is not totally unexpected given that ants can dehydrate quite rapidly. Studies on humidity preferences of the same four species of fire ants, in the absence of superimposed temperature gradients (Potts et al., 1984), revealed that broodless worker ants failed to make scorable choices in a humidity gradient, whereas brood-tending workers always preferred near-saturated relative humidities. When tested at $22^{\circ} \mathrm{C}$, this response of negative hydrokinesis required up to 24 hours to become expressed.

These ground-nesting ants build mounds to variable extents depending on soil texture and moisture levels. The soil profile has a thermal gradient which varies with daily and seasonal cycles of insolation. Relative humidity at any given depth in the ant tunnels is influenced by the soil moisture and the temperature at that level. Thus, by detecting temperature and humidity gradients in their nest 

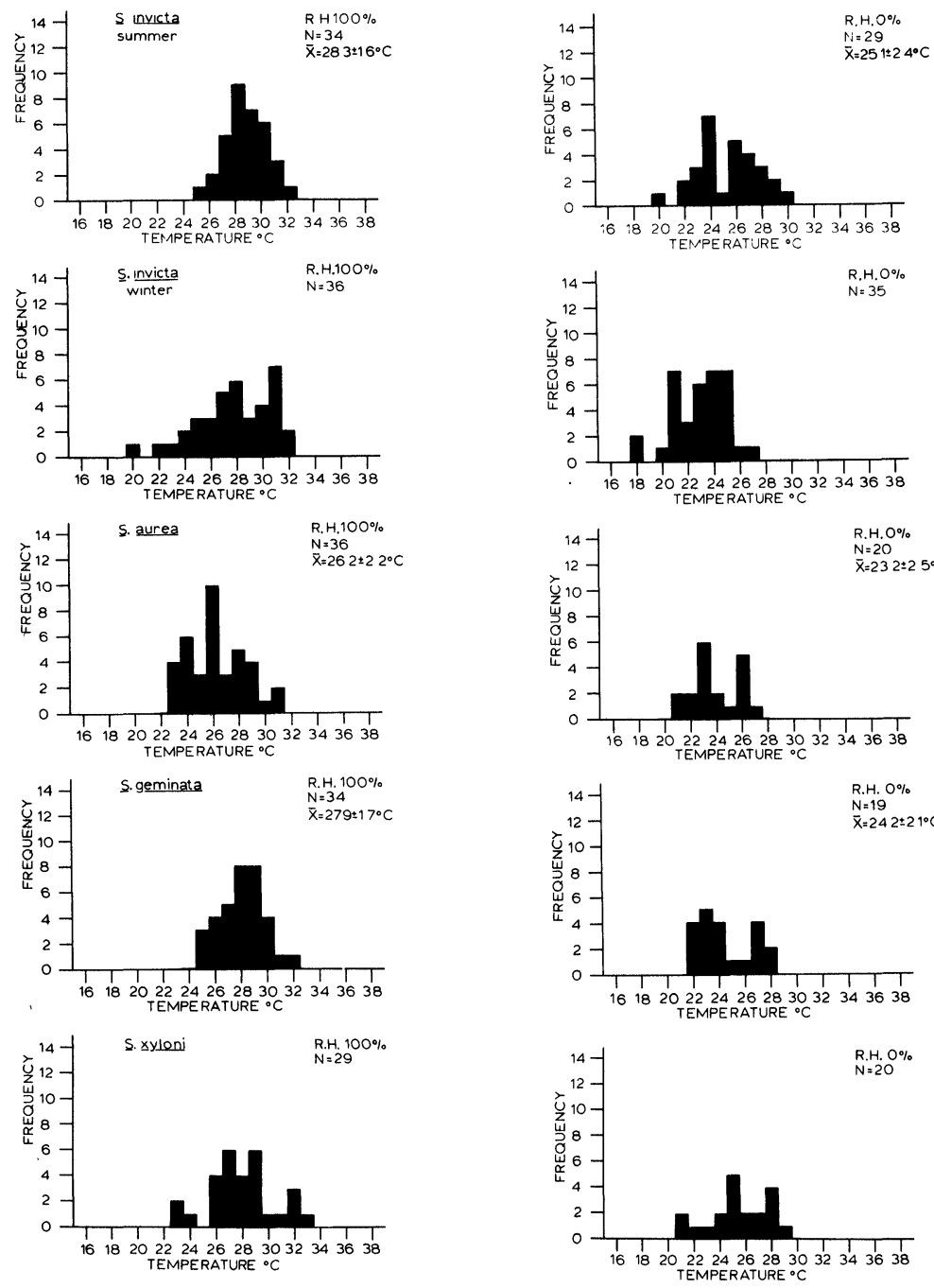

Fig. 2. Temperature preference responses of four species of fire ants (Solenopsis invicta, $S$. aurca, $S$. geminata, and $S$. ry loni) and preference responses of $S$. invicta collected during different seasons (summer and winter); graphs on right represent responses at $0 \%$, left represent responses at $100 \%$ relative humidities. When acclimation was significant, mean temperature preferences are given in Table 1. 
the ants can move the brood to optimize the Darwinian fitness of the colony. The "optimum" temperature for fast brood development is often associated with reduced relative humidities which endanger brood survival. Alternatively, saturated air might be present only at soil depths where temperatures are less than optimal for development and survival. Thus, the ants apparently monitor these two environmental factors continuously, and move the brood accordingly to optimize colony growth and productivity. In addition, by shifting the seasonal peak of reproduction, and the daily peak of foraging, the ants can avoid the extremes in temperature and relative humidity which are detrimental to their survival.

The differences in the ecogeographic distribution of the four species of fire ants studied can not be explained simply by differences in their responses in a temperature gradient. Interspecific comparisons among species indicate that the most xeric species, $S$. aurea, has the lowest preferred temperatures at both $0 \%$ and $100 \% \mathrm{R}$. H. The two mesic species, $S$. geminata and $S$. invicta, follow in that order, respectively. The widespread species, $S$. xyloni, has the highest preferred temperature at both $0 \%$ and $100 \%$ R. H., and it also showed a significant acclimation effect. Ants acclimated at $32^{\circ} \mathrm{C}$ had the lowest preferred temperatures, followed by those acclimated at $12^{\circ} \mathrm{C}$ and $22^{\circ} \mathrm{C}$, respectively. These results suggest that ants held at $32^{\circ} \mathrm{C}$ might have been under some type of water stress, and that the brood-tending workers of $S$. xyloni responded faster to this environmental factor than the brood-tending workers of the other species. Perhaps this faster response time to the needs of the brood is correlated with the broader ecogeographical distribution of S. xyloni.

Comparison of the temperature preferences of fire ants with those of other ant species have limited value because of the paucity of data, and the differences in experimental protocols. The only previous study in which both moisture gradients and effects of pheromones (from earlier experimental trials) were adequately controlled was that of Brian (1973). He reported that Myrmica rubra L. from England, when tested at $100 \%$ R. H., preferred temperatures in the 19 to $21^{\circ} \mathrm{C}$ range. It is interesting to note that the temperature preferences of $M$. rubra are about $8^{\circ} \mathrm{C}$ lower than those of the fire ants collected at lower latitudes. Additional species need to be studied before any generalizations can be made about relationships between latitudal/altitudinal distributions of ants and their temperature preferences. 


\section{SUMMARY}

The temperature preferences of brood-tending fire ants were determined with a linear temperature gradient. The following four species of fire ants were used: Solenopsis aurea, the desert fire ant; $S$. geminata, the tropical fire ant; $S$. invicta, the red imported fire ant; and S. xyloni, the southern fire ant. The responses of ants acclimated at $12^{\circ}, 22^{\circ}$, and $32^{\circ} \mathrm{C}$ were determined at both $0 \%$ and $100 \%$ relative humidity. The four species differed slightly in their temperature preferences at $100 \%$ R. H. $\left(26.2,27.9,28.3\right.$, and $29.7^{\circ} \mathrm{C}$, respectively). Temperature preferences were reduced by $3-4^{\circ} \mathrm{C}$ at $0 \%$ R. H. (23.2, 24.2, 25.1, and $25.4^{\circ} \mathrm{C}$, respectively). Prior acclimation was significant only on $S$. xyloni, and on $S$. invicta collected in the winter. The differences in the responses of the four species are not clearly correlated with their ecogeographical distributions.

\section{ACKNOWLEDGEMENTS}

We wish to thank William P. MacKay, Sherman A. Phillips, Jr., Sanford D. Porter, James K. Wangberg, and R. Jeffery Whitworth for their comments on the manuscript. We would also like to thank the following individuals who aided in the collection of ants: Mike Bishop, Lori Braulick, Robin Kral, Mike McCormick, William P. Morrison, Lindsey R. Potts, and William Rogers. Lindsey R. Potts assisted in the data analysis and Mary L. Peek and Lorie A. Prien typed the manuscript.

This study was supported by the Texas Department of Agriculture Interagency Agreements IAC (80-81)-0463, (81-82)-0806, and (82-83)-1651. Contribution No. T-10-156, College of Agricultural Sciences, Texas Tech University.

\section{RHFEREN'}

Banks, W. A., C. S. Lofgren, D. P. Joungnaz, C. E. Stringer, P. M. Bishop, D. F. Willi.iAMs, D. P. WOJC'IK, AND B. M. Glanc'EY, 1981. Techniques for collecting, rearing, and handling imported fire ants. U. S. D. A., Sci. Education Admin., Advances in Agric. Tech., Southern Ser., No. 21, pp. 1-9.

BRIAN, M. V., 1973. Temperature choice and its relevance to brood survival and caste determination in the ant Myrmica rubra L. Physiol. Zool., 46(4): 245-252.

Bull, E., AND R. W. Mitchill, 1972. Temperature and relative humidity responses of two Texas cave-adapted millipedes, Cambala speobia (Cambalida: Cambalidae) and Speodesmus hicornourus (Polydesmida: Vanhoeffeniidae). Internat. J. Speleol., 4: 365-393. 
Ceusters, R., 1977. Social homeostasis in colonies of Formica polyctena Foerst. (Hymenoptera, Formicidae): Nestform and temperature preferences. Proc. Eighth Internat. Cong. Internat. Union Stud. Social Insects, Wageningen, Netherlands Sept. 5-10, 1977, pp. 111-112.

DEAl., J., 1941. The temperature preferendum of certain insects. J. Animal Ecol., 10: 323-356.

Ferguson, D. E., and J. D. Land, 1961. Some temperature studies on the beetle, Popilius disjunctus. Ecology, 42(1): 195-197.

Fralinki:L, G. S., AND D. L. GunN, 1961. The orientation of animals: Kineses, taxes and compass reactions. Dover Publ., Inc. New York, $x+376$ pp.

Francke, O. F., J. C. Cokendol.pher, A. H. Horton, S. A. Phill.ips, Jr., and L. R. PotTs, 1983. Distribution of fire ants in Texas. Southwest. Entomol., 8: 32-41.

GunN, D. L. AND C. A. Cosway, 1938. The temperature and humidity relations of the cockroach. IV. Preferred temperature at different absolute humidities. J. Exper. Biol., 15: 559-563.

Hi:INRIC'I, B., editor, 1981. Insect Thermoregulation. John Wiley \& Sons, New York, $328 \mathrm{pp}$.

Heilwig, J. T., AND K. A. Council, editors, 1979. SAS User's Guide, 1979 edition. Statistical Analysis System Institute Inc., Cary, North Carolina, 494 pp.

HENson, W. R., 1960. The effect of aggregation on the behavior of a beetle (Conophthorus coniperda S7.) in a temperature gradient. Yale J. Biol. Medicine, 33: $128-132$.

MadGE, D. S., 1961. "Preferred Temperatures" of land arthropods. Nature, 190: 106-107.

MADGE, D. S., 1965. The behavior of Belha geniculosa Oudms. and certain other species of oribatid mites in controlled temperature gradients. Acarologia, 7: 389-406.

MoRI, H., 1961. Comparative studies of thermal reaction in four species of spider mites (Acarina: Tetranychidae). J. Faculty Agricul. Hokkaido Univ., 51(3): 574-591.

Potts, L. P., O. F. Franc'ke and J. C. Cokendolpher, 1984. Humidity preferences of four species of fire ants (Hymenoptera: Formicidae: Solenopsis). Insectes Sociaux. 31: 335-340.

Protomastro, J. J., 1973. Relación entre el comportamiento de crianza y un ritmo diario de preferencia térmica en la hormiga Camponotus mus Roger. Physis, Sec. C, 3: 123-128.

Seeley, T. AND B. HeinRici, 1981. Regulation of temperature in the nests of social insects. Pp. 159-234. In Insect Thermoregulation (B. Heinrich, editor). John Wiley \& Sons, New York, 328 pp.

Siegel, S., 1956. Nonparametric Statistics for the Behavioral Sciences. McGrawHill Book Company, Inc., New York, 312 pp.

Singi, P., M. T. M(Ellistrem, ANd J. G. Rodrigliez, 1967. The response of some macrochelids to temperature and humidity (Acarina: Macrochelidae). Acarologia, 9: 1-19. 

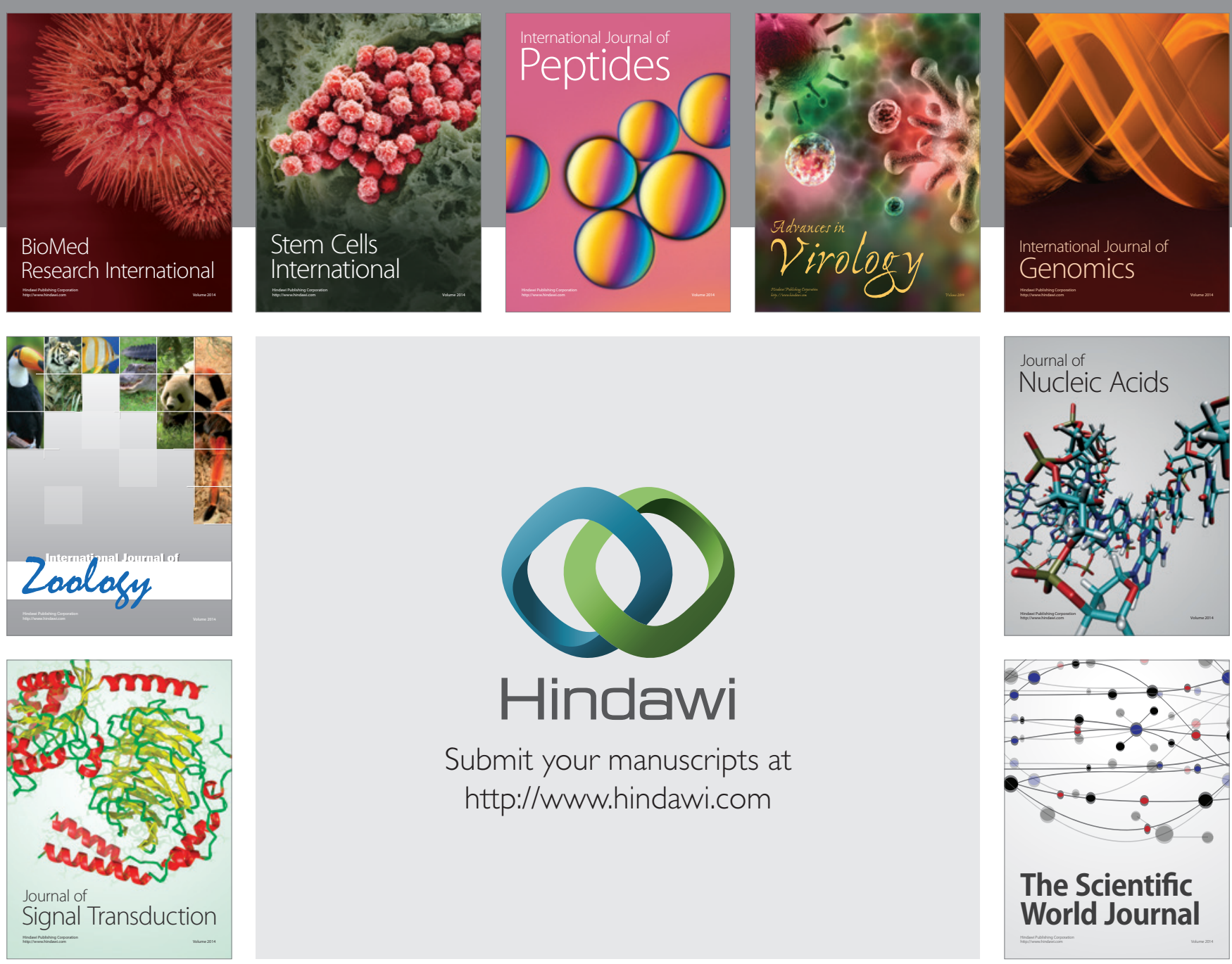

Submit your manuscripts at

http://www.hindawi.com
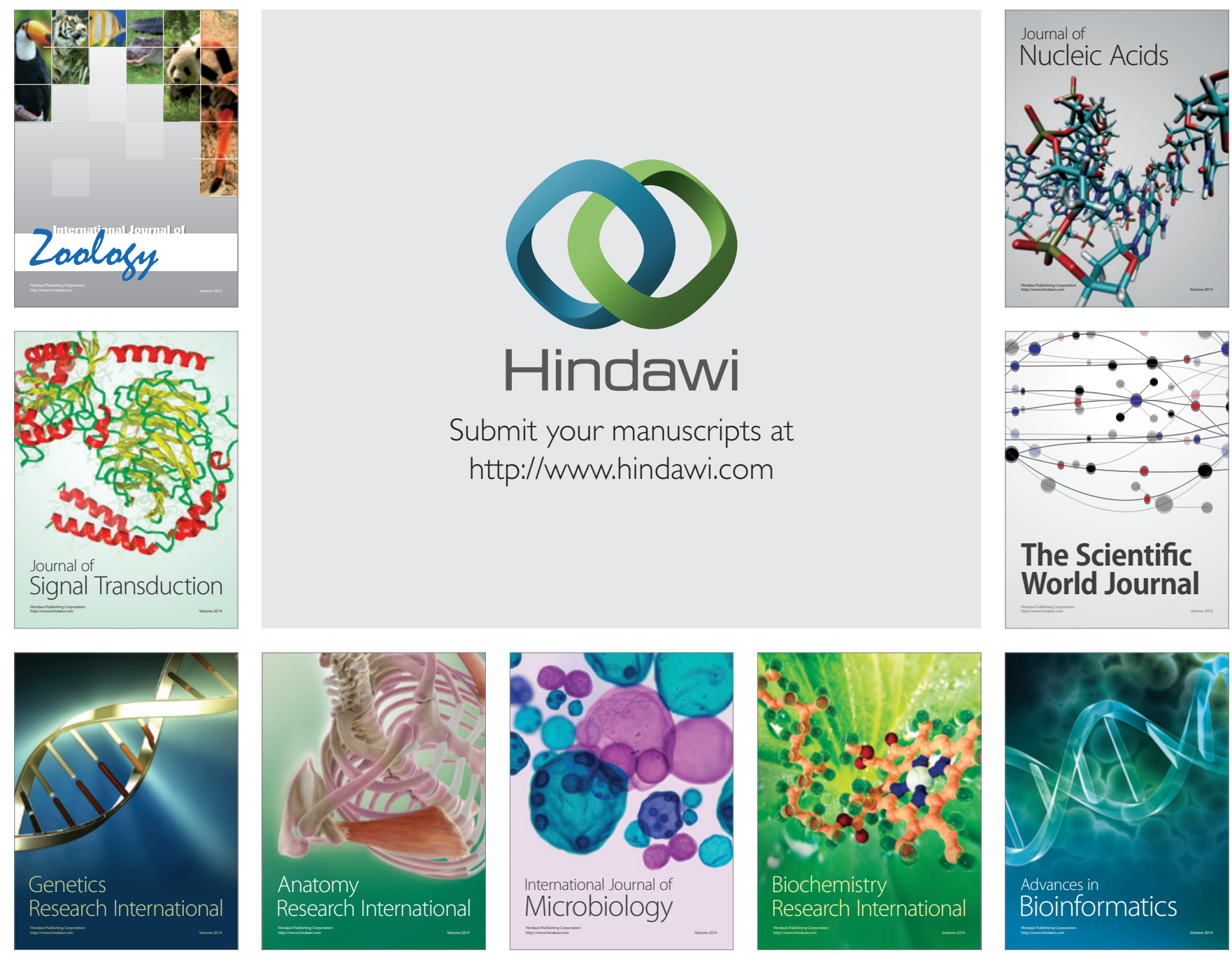

The Scientific World Journal
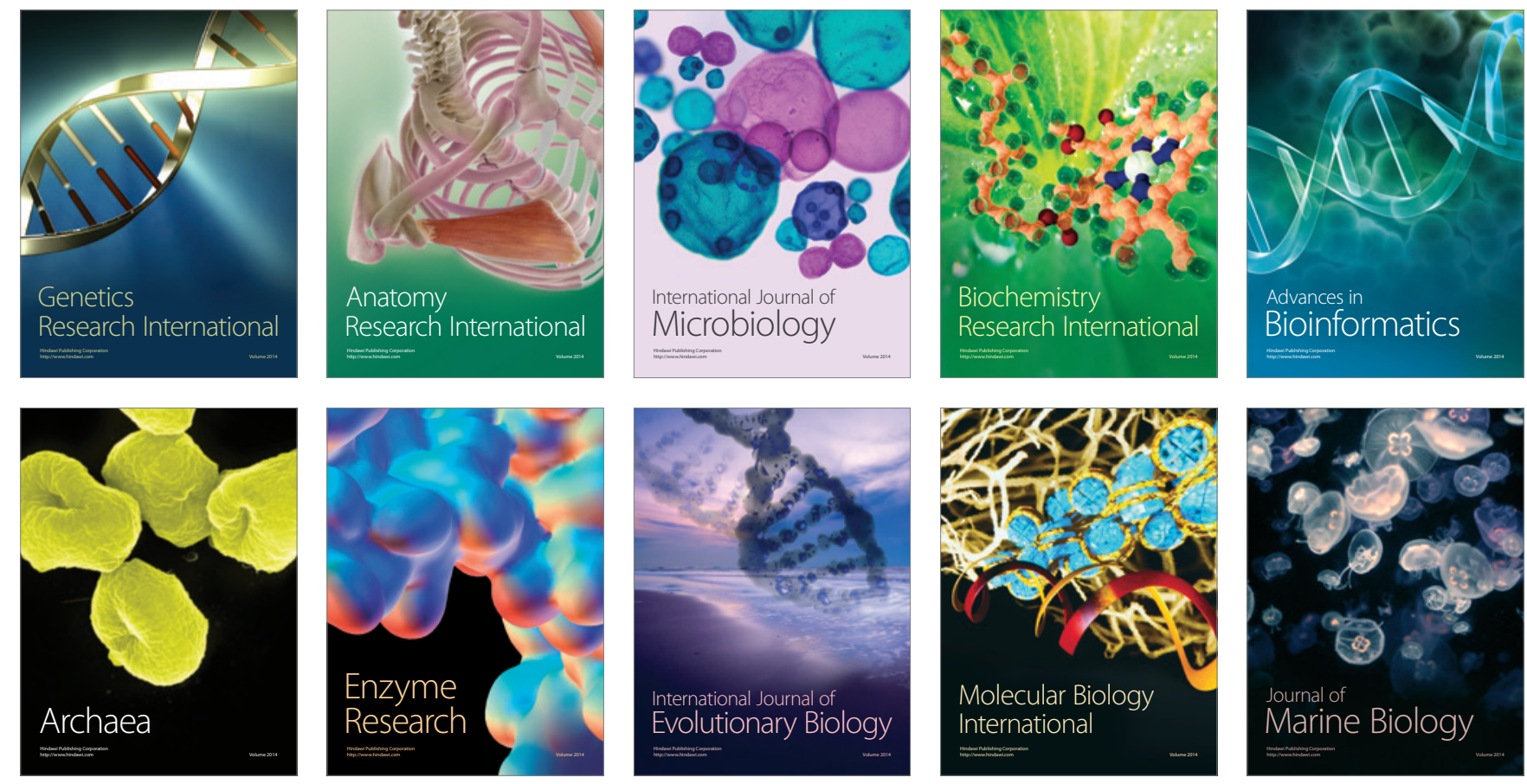